\title{
Block-excision of cystic epithelial downgrowth as the treatment of choice
}

A Viestenz and GOH Naumann

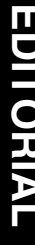

\section{Eye (2005) 19, 1. doi:10.1038/sj.eye.6701481}

Cystic or diffuse epithelial downgrowth into the anterior chamber after trauma or intraocular surgery is a rare complication. The correct first therapeutic approach determines the survival of the eye. Direct manipulation of the cyst wall may lead to a transformation from cystic to diffuse invasion, resulting in irreversible glaucomas and loss of the globe. ${ }^{1-3}$

A number of therapies have been tried to treat those eyes: 'peeling' of the cyst wall, photocoagulation, or injection of epitheliotoxic solutions. ${ }^{4,5}$ The very intimate connection between epithelial cells, trabecular meshwork, ciliary band, iris surface, and corneal endothelium always occurs with involvement of the angle. ${ }^{1-3}$ In view of these

ophthalmopathologic details, it is impossible to peel this very delicate cystic wall. The cyst wall consists of only a few up to 12 layers of stratified epithelium. ${ }^{6}$ The alcohol injection technique $\mathrm{e}^{5}$ leads to incomplete destruction of the thicker layers of intraocular epithelial cells and/or severe intraocular irritation. Laser coagulation frequently result's in an opening of the cyst with spreading of epithelial cells into all of the anterior segment structures, - this option leads to disastrous surgical outcome. ${ }^{2,4}$

The curative approach is a blockexcision of cystic epithelial downgrowth involving the angle-using all adjacent tissue of cornea, sclera, pars plicata of ciliary body, and iris as a 'shell' ${ }^{1-3,7}$ The resulting defect of the globe is then closed by a tectonic corneoscleral graft. This in our experience is the treatment of choice if the cyst involves less than five clock hours of the circumference. ${ }^{1-3,7}$ In our consecutive series (1980-2003) of 59 referred patients with epithelial ingrowth, no recurrence was observed, and no enucleation after blockexcision was needed (mean follow-up: 69 months). ${ }^{1-3,7}$ In view of the extent of the procedure, the loss of only one line of visual acuity is acceptable. Only two eyes developed hypotony after excisions involving more than $150^{\circ}$.

Cystic epithelial downgrowth enlarges slowly over time, probably because of the corneal endothelial cover. ${ }^{7,8}$ If a donor corneoscleral graft for tectonic wound closure is not available, the use of syngeneic auricular cartilage appears to be an interesting alternative. Cartilage as a primary avascular tissue containing collagenous fibres might offer the advantages of no graft reaction because of its syngeneic nature. Longterm results need to be evaluated. The technique, described by Ganesh et al in this issue of 'Eye', potentially offers a promising new surgical approach for closure of defect in the eyewall following blockexcision for epithelial ingrowth.

\section{References}

1 Naumann GOH, Völcker HE. Blockexzision intraokularer Prozesse. II. Epitheleinwachsungen in das vordere Augensegment. Klin Monatsbl Augenheilkd 1975; 166: 448-457.

2 Naumann GOH, Rummelt V. Block excision of cystic and diffuse epithelial ingrowth of the anterior chamber. Report on 32 consecutive patients. Arch Ophthalmol 1992; 110: 223-227.

3 Naumann GOH. The Bowman Lecture. Eye 1995; 9 : 395-421.

4 Groh MJM, Nguyen NX Küchle M, Naumann $\mathrm{GOH}$. Umwandlung der zystischen in eine diffuse Epithelinvasion durch Laser-Zysteneröffnung. Bericht über 4 Patienten. Klin Monatsbl Augenheilkd 2002; 219: 37-39.

5 Behrouzi Z, Khodadoust A. Epithelial iris cyst treatment with intracystic ethanol irrigation. Ophthalmology 2003; 110: 1601-1604.

6 Küchle M, Green WR. Epithelial ingrowth: a study of 207 histopathologically proven cases. German J Ophthalmol 1996; 5: 211-223.

7 Viestenz A, Küchle M, Naumann GOH. Block excision of epithelial ingrowth after cataract surgery - report on 15 patients. Klin Monatsbl Augenheilkd 2003; 220: 465-470.

8 Zagorski Z, Shrestha HG, Lang GK, Naumann GOH. Sekundärglaukome durch intraokulare Epithelinvasion. Klin Monatsbl Augenheilkd 1988; 193: $16-20$
Department of Ophthalmology University Erlangen-Nuernberg Schwabachanlage 6 Erlangen D-91054 Germany

Correspondence: A Viestenz Department of Ophthalmology University Erlangen-Nuernberg Schwabachanlage 6 Erlangen D-91054 Germany

Tel.: + 49-9131-8533001

Fax: + 49-9131-8536401

E-mail: Arne.Viestenz@ t-online.de 